УДК: 378.016:821.161.2]:008:614.253.4

DOI: $10.26697 /$ ijes.2019.2.24

\section{Шляхи формування мовленнсвого етикету професійного спілкування іноземного студента-медика}

Доцент Цуркан М. В. ${ }^{1}$

${ }^{1}$ Вищий державний навчальний заклад Украйни “Буковинський державний медичний університет”, Україна

\begin{abstract}
Резюме
Вступ:

Формування професійної мовленнєвої компетенції іноземного студента-медика включає в себе ознайомлення іноземця 3 мовленнєвим етикетом як мікросистемою національно специфічних стійких формул спілкування, прийнятих i прописаних суспільством для встановлення контакту на рівні “лікар - пацієнт”, “лікар - асистент”, “лікар студент-медик”, “лікар - провізор”, “лікар - родич хворого". Мета дослідження - визначити шляхи формування мовленнєвого етикету професійного спілкування іноземного студента-медика в процесі навчання української мови як іноземної.
\end{abstract}

\section{Методи:}

Дослідження грунтується на використанні описового методу та методу педагогічного спостереження.

\section{Результати:}

Шляхи формування мовленнєвого етикету студента-іноземця суттєво відрізняються від засвоєння подібних формул етикету українськими студентами, адже для носіїв мови цей процес відбувається природно в контексті набуття досвіду "живого" спілкування і вже тільки вдосконалюється в ході здобуття професійної освіти. Формування мовленнєвого етикету іноземця перебуває в силовому полі міжкультурної комунікації, де, окрім мовних бар'єрів, додаються національно марковані правила формального i неформального спілкування, що часто не збігаються і не співвідносяться 3 правилами їхньої етнокультури. При цьому це засвоєння основних професійних кліше спочатку відбувається в умовах штучно змодельованих ситуацій у контексті формування діалогічного мовлення, і лише з часом переходить від змодельованого до реального спілкування з українським пацієнтом.

Основним напрямом вивчення i засвоєння мовленнєвого етикету іноземними студентамимедиками $\epsilon$ інтеграція цього процесу зі стратегіями формування комунікативної, лінгвістичної, соціокультурної та передусім професійно зорієнтованої компетентностей, що забезпечать уміння ефективно використовувати українську мову в різноманітних ситуаціях фахового спілкування на основі реалізації комунікативнодіяльнісного та компетентнісного підходів.

Початковим етапом опанування мовленнєвого етикету повинно стати ознайомлення студентаіноземця 3 етичними мовленнєвими нормами.
Перші труднощі, з якими зустрічається студент, $\epsilon$ відсутність в їхньому мовленнєвому етикеті звертання у формі “пошанної множини", тобто звертання до пацієнта на "Ви”, що в майбутньому реальному спілкуванні 3 українським пацієнтом може стати підгрунтям і професійного, і навіть расового конфлікту, адже звичне для іноземця звертання “ти” буде сприйнято як панібратство чи фамільярність.

Задля опанування клінічних предметів майбутньому лікареві необхідно навчитися будувати діалог із пацієнтом для збору анамнезу i заповнення медичної карти. Тому особливу увагу на заняттях із української мови як іноземної варто приділити мовному практикуму 3 побудови питальних речень на основі професійної лексики. Крім коректного вживання питальних слів, варто акцентувати увагу іноземця на порядок слів та логічні наголоси, які часто можуть впливати на конотативні відтінки цілого речення. Наступним, більш складним шляхом формування мовленнєвого етикету, є вироблення тактики спілкування на рівні “лікар (студент-медик) - пацієнт”, адже від тактичних мовленнєвих прийомів залежить якість отриманої інформації від хворого, здатність спрямувати процес передачі текстових повідомлень, реплік у потрібне русло, перехопити й утримати ініціативу в бесіді, активізувати увагу пацієнта, зробити спілкування більш ефективним. Наступний напрям - це розвиток в студента вміння слухати і сприймати “живе” мовлення (не завжди літературне, часто 3 використанням діалектної (невідомої іноземцеві) лексики і просторіччя). Вміння слухати - це важливий показник культури мовця, однак у випадку із іноземцем важливо ознайомити студента 3 формулами ввічливості, якими він може перепитати чи уточнити незрозумілу інформацію, опанувати певні мовні кліше, щоб коректно реалізувати інтенції вітання, подяки, співчуття, прохання й т. п. Завершальний етап - оволодіння паралінгвістичними засобами мовлення (сила голосу, темп, мелодика, пауза).

\section{Висновки:}

Мовленнєвий етикет майбутнього лікаря-іноземця $\epsilon$ важливим атрибутом його професійного становлення як професіонала, i як особистості, тому запропоновані шляхи його формування найбільш ефективні в контексті професійної мовленнєвої комунікації, зокрема проведення рольових ігор “лікар - пацієнт".

\section{Інформація про автора:}

Цуркан Марія Валентинівна - кандидат філологічних наук, доцент кафедри суспільних наук та українознавства, ВДНЗ України "Буковинський державний медичний університет", Чернівці, Україна.

Наукові інтереси: стилістика, лінгвістика тексту; https://orcid.org/0000-0003-2866-1743.

\section{Автор-Кореспондент:}

Цуркан Марія Валентинівна

Email Автора-Кореспондента:

marichka-77@ukr.net 